\title{
RESPIRATORY BURST INDUCED BY PHORBOL ESTER IN THE PRESENCE OF TAUTOMYCIN, A NOVEL INHIBITOR OF PROTEIN PHOSPHATASES
}

\author{
Juni Magae, Ayako Hino, Kiyoshi Isono ${ }^{\dagger}$ and Kazuo NaGaI \\ Department of Bioengineering, Tokyo Institute of Technology, \\ Nagatsuta, Midori-ku, Yokohama 227, Japan \\ 'RIKEN, The Institute of Physical and Chemical Research, \\ Wako-shi, Saitama 351-01, Japan \\ (Received for publication September 5, 1991)
}

\begin{abstract}
Phorbol dibutyrate induced a nitroblue tetrazolium-reducing reaction in differentiated HL-60 cells, which was inhibited by protein kinase inhibitors such as staurosporine and H-7. ID ${ }_{50}$ of staurosporine and $\mathrm{H}-7$ were $1.4 \mathrm{ng} / \mathrm{ml}$ and $0.19 \mathrm{~mm}$, respectively. When tautomycin, an inhibitor of protein phosphatases, was added with the kinase inhibitors, the nitroblue tetrazolium-reducing reaction again appeared. $\mathrm{ID}_{50}$ of staurosporine was $510 \mathrm{ng} / \mathrm{ml}$ in the presence of tautomycin. Tautomycin itself weakly induced the reaction, which was inhibited by kinase inhibitors. Such a competitive effect between tautomycin and staurosporine was not observed in a cell-free system of protein kinase $\mathrm{C}$. Okadaic acid had the same effect as tautomycin. The similar results were obtained when respiratory burst was quantitated by measuring $\mathrm{H}_{2} \mathrm{O}_{2}$ produced by canine peripheral neutrophils. The mechanism of competitive effect of tautomycin and staurosporine on respiratory burst is discussed.
\end{abstract}

Tautomycin is a 2,3-dialkyl maleic anhydride antibiotic produced by Streptomyces spiroverticillatus ${ }^{1 \sim 3)}$. The compound was first isolated as an antifungal antibiotic and further study revealed that it induces blebs on the surface of human leukemia, $\mathrm{K} 562 \mathrm{cells}^{4}$. Similar morphological change is also induced by phorbol ester, cytochalasin D or okadaic acid ${ }^{4,5)}$.

Tautomycin enhances phosphorylation of several proteins in vivo. Similar enhancement of phosphorylation was also observed with okadaic acid, an inhibitor of protein phosphatases, but not with phorbol ester or cytochalasin D. Furthermore, tautomycin as well as okadaic acid inhibited activity of protein phosphatases extracted from mouse brain in a cell-free system ${ }^{5}$. Further studies have revealed that tautomycin preferentially inhibits type-1 and $-2 \mathrm{~A}$ protein phosphatases from skeletal muscle and smooth muscle ${ }^{6,7)}$.

Recently, it was reported that calyclin-A, which inhibited type-1 and $-2 \mathrm{~A}$ protein phosphatases ${ }^{8}$, induced rapid morphological change of mouse fibroblast cells ${ }^{9}$. Therefore, it seems likely that inhibition of protein phosphatases causes the morphological change of $\mathrm{K} 562$ cells. In this report, regulation of respiratory burst through protein phosphatases was studied.

\section{Materials and Methods}

\section{Chemicals}

Tautomycin, staurosporine and quinomycin were purified in our laboratory from the culture broth of actinomycetes. Okadaic acid was kindly given from Dr. FuJıKI.

Nitroblue Tetrazolium (NBT)-reducing Reaction

Experiments were carried out as described previously ${ }^{4)}$. In brief, HL-60 cells differentiated to mature granulocytes by incubating with $1 \mathrm{ng} / \mathrm{ml}$ quinomycin for 3 days, were cultured with appropriate agents in 
the presence of $1 \mathrm{mg} / \mathrm{ml} \mathrm{NBT}$ for 1 hour at $37^{\circ} \mathrm{C}$. Cells containing formazan deposits were counted microscopically. $50 \sim 90 \%$ cells contained deposits when stimulated with $100 \mathrm{ng} / \mathrm{ml}$ phorbol dibutyrate $(\mathrm{PDBu})$.

\section{Protein Kinase C (PKC) Assay}

PKC from K562 cells was partially purified by DEAE-Sephacel column ${ }^{4,10)}$. PKC activity was assayed by measuring the amount of ${ }^{32} \mathrm{P}$ exchange between $\left[\gamma^{32} \mathrm{P}\right] \mathrm{ATP}$ and histone III-S in the presence of $\mathrm{PKC}^{4,10}$. Reaction mixture contained $20 \mathrm{mM}$ Tris - $\mathrm{HCl}(\mathrm{pH} 7.5), 5 \mathrm{~mm}$ 2-mercaptoethanol, $10 \mathrm{mM} \mathrm{MgCl}_{2}, 1 \mathrm{~mm} \mathrm{CaCl}, 20 \mu \mathrm{g} / \mathrm{ml}$ phosphatidylinositol, $70 \mu \mathrm{M}\left[\gamma_{-}{ }^{32} \mathrm{P}\right] \mathrm{ATP}, 0.75 \mathrm{mg} / \mathrm{ml}$ histone III-S, $15 \mu \mathrm{g}$ enzyme and the reagents as indicated.

Measurement of $\mathrm{H}_{2} \mathrm{O}_{2}$ Produced by Canine Neutrophils

Blood was collected from healthy dogs and the neutrophils were separated by Lymphoprep (Daiichi Pure Chemicals). More than $90 \%$ cells were usually neutrophils. $\mathrm{H}_{2} \mathrm{O}_{2}$ was assayed according to the method of COHEN et al. ${ }^{11)}$. Three million cells $/ \mathrm{ml}$ neutrophils were incubated in HANK's balanced salt solution containing $0.2 \mathrm{mg} / \mathrm{ml}$ phenol red and 10 units $/ \mathrm{ml}$ horse radish peroxide. At the termination of the culture, $50 \mathrm{~mm} \mathrm{NaOH}$ was added. $\mathrm{A}_{600}$ of the supernatant was measured.

\section{Results}

As shown previously ${ }^{4}$, tautomycin only slightly induced the NBT-reducing reaction as compared with PDBu (Fig. 1). The NBT-reducing reaction induced by PDBu, as well as that induced by tautomycin were completely inhibited by the addition of kinase inhibitors such as $30 \mathrm{ng} / \mathrm{ml}$ staurosporine and $1 \mathrm{~mm}$ H-7. However, it was shown to be highly resistant to the kinase inhibitors when both PDBu and tautomycin were present in the reaction mixture. In contrast, staurosporine inhibited the protein phosphorylation which was mediated by PKC in a cell-free system at the same level whether tautomycin was present or not (Fig. 2); this indicated that tautomycin does not directly compete with staurosporine.

Okadaic acid, a potent inhibitor of protein phosphatases ${ }^{12)}$ with a different structure from that of tautomycin ${ }^{13)}$, also slightly induced the NBT-reducing reaction and modified the NBT-reducing reaction

Fig. 1. Tautomycin suppressed inhibition of NBT-reducing reaction by kinase inhibitors.

NBT-reducing reaction was induced by tautomycin $(O), \operatorname{PDBu}(\triangle), \operatorname{PDBu}$ and tautomycin $(\bullet)$ in the presence of staurosporine (A) and $\mathrm{H}-7$ (B).

(A)

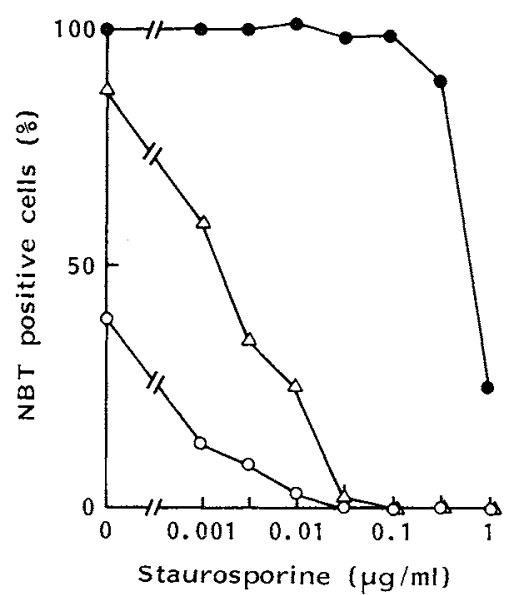

(B)

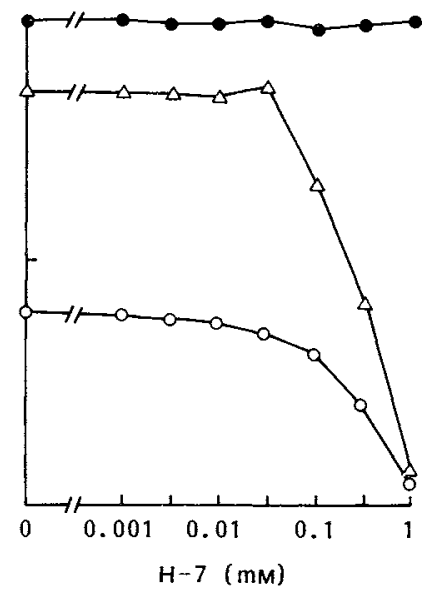

Tautomycin $10 \mu \mathrm{g} / \mathrm{ml}$ and PDBu $100 \mathrm{ng} / \mathrm{ml}$ were used. 
Fig. 2. Tautomycin did not suppress inhibitory effect of staurosporine in a cell-free system.

(A)

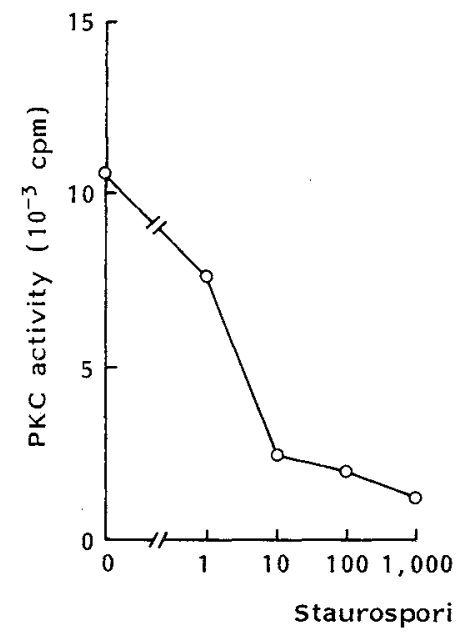

(B)

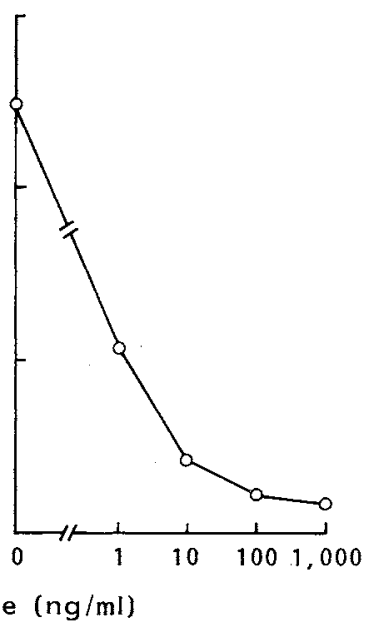

Phosphorylation mediated by PKC was carried out in the absence (A) or the presence (B) of tautomycin. Staurosporine and tautomycin was added at the initiation of the reaction.

Fig. 3. Okadaic acid suppressed inhibition of NBTreducing reaction by staurosporine.

NBT-reducing reaction was induced by okadaic acid $(0), \operatorname{PDBu}(\bullet)$ and okadaic acid and $\operatorname{PDBu}(\triangle)$ in the presence of staurosporine.

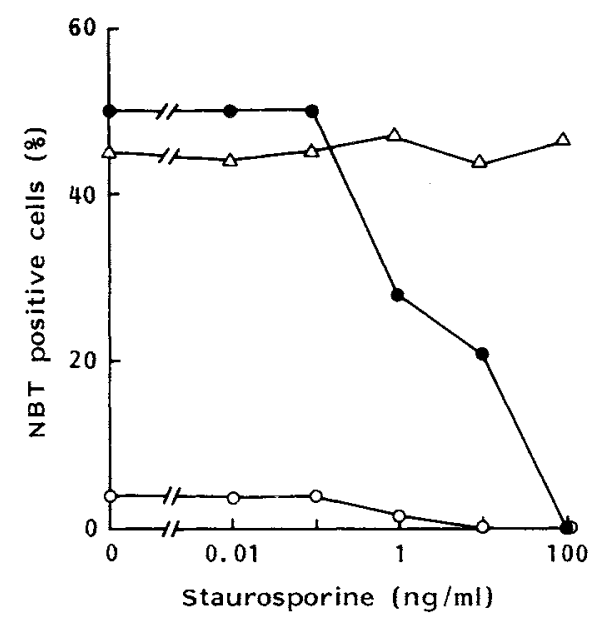

$\mathrm{PDBu} 100 \mathrm{ng} / \mathrm{ml}$ and okadaic acid $30 \mu \mathrm{g} / \mathrm{ml}$ were used.
Fig. 4. Effect of tautomycin on $\mathrm{H}_{2} \mathrm{O}_{2}$ production of canine neutrophils.

Respiratory burst was induced by PDBu (100 ng/ml) in the absence (-) or the presence of staurosporine $(10 \mathrm{ng} / \mathrm{ml} \bigcirc, 100 \mathrm{ng} / \mathrm{ml} \square, 1,000 \mathrm{ng} / \mathrm{ml} \triangle$ ).

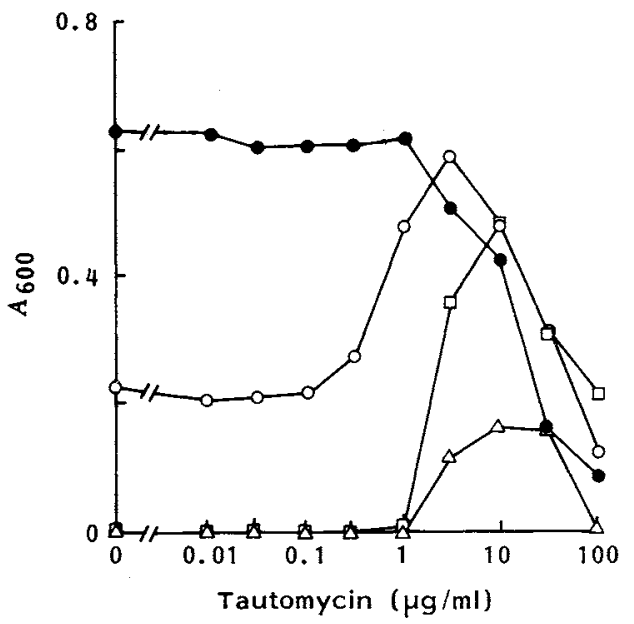

Tautomycin was added at the initiation of the culture. After a 1 hour incubation, $\mathrm{H}_{2} \mathrm{O}_{2}$ produced was measured as described in Materials and Methods.

induced by PDBu which is highly resistant to staurosporine (Fig. 3). The result suggests that inhibition of protein phosphatases is involved in the competitive effect of tautomycin. Cytochalasin D did not suppress the inhibitory effect of staurosporine (data not shown) although it induces similar morphological change of K562 cells to that induced by tautomycin. ${ }^{4)}$ 
Fig. 5. Tautomycin suppressed inhibition of $\mathrm{H}_{2} \mathrm{O}_{2}$ production of canine neutrophils pretreated with staurosporine.

Neutrophils were incubated with PDBu $(100 \mathrm{ng} / \mathrm{ml})$ in the presence $(\boldsymbol{\Delta}, \Delta)$ or absence $(\bullet, 0)$ of staurosporine $(100 \mathrm{ng} / \mathrm{ml})$. Tautomycin $(30 \mu \mathrm{g} / \mathrm{ml})$ was added 30 minutes later $(\triangle, 0)$.

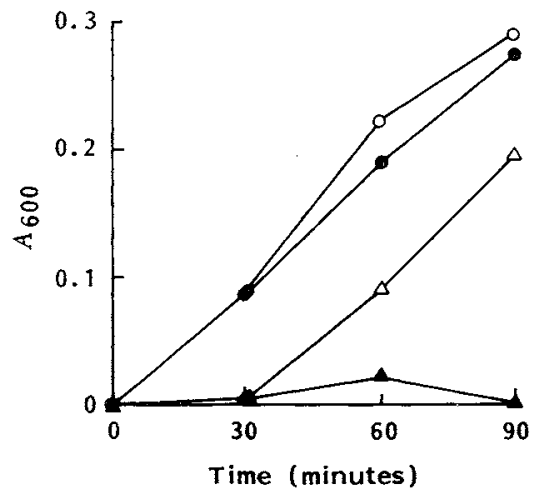

$\mathrm{H}_{2} \mathrm{O}_{2}$ produced was measured at the indicated time as described in Materials and Methods.
Fig. 6. Tautomycin did not suppress inhibitory effect by $4-p-\mathrm{BPB}$.

NBT-reducing reaction was induced by $\mathrm{PDBu}(\mathbf{0})$, or tautomycin and PDBu $(O)$ in the presence of 4- $p$-BPB.

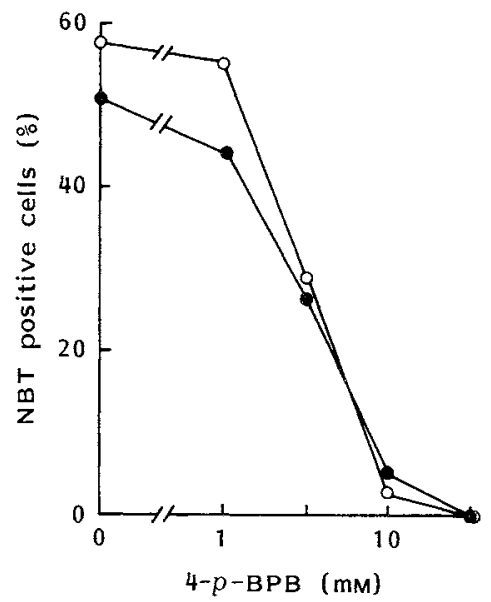

Tautomycin $30 \mu \mathrm{g} / \mathrm{ml}$ and PDBu $100 \mathrm{ng} / \mathrm{ml}$ were used.

Since the assay of the NBT-reducing reaction was qualitative and HL-60 was a malignant cell line, $\mathrm{H}_{2} \mathrm{O}_{2}$ production caused by respiratory burst of normal neutrophils was measured using canine peripheral neutrophils (Fig. 4). Neutrophils produced $\mathrm{H}_{2} \mathrm{O}_{2}$ time dependently up to 3 hours in response to $\mathrm{PDBu}$. In these circumstances, tautomycin did not induce respiratory burst. Staurosporine inhibited the $\mathrm{H}_{2} \mathrm{O}_{2}$ production at $0.1 \mu \mathrm{g} / \mathrm{ml}$. The inhibition was suppressed by the addition of $3 \mu \mathrm{g} / \mathrm{ml}$ tautomycin. Unlike the case of the NBT-reducing reaction, tautomycin itself inhibited the $\mathrm{H}_{2} \mathrm{O}_{2}$ production which was induced by PDBu. If tautomycin was added 30 minutes after the treatment with PDBu and staurosporine, neutrophils produced $\mathrm{H}_{2} \mathrm{O}_{2}$ and the reaction had the same kinetics as when it was induced by PDBu alone (Fig. 5). This suggests that tautomycin does not block the uptake of staurosporine.

The NBT-reducing reaction induced by PDBu was inhibited by 4-p-bromophenacyl bromide (4- $p$ $\mathrm{BPB}$ ), an inhibitor of phospholipase $\mathrm{A}_{2}$ (Fig. 6). The reaction induced by tautomycin and PDBu was also inhibited by 4- $p$ - $\mathrm{BPB}$, indicating that the activation of phospholipase $\mathrm{A}_{2}$ is necessary even in the presence of tautomycin. A similar result was obtained in the experiment in which $\mathrm{H}_{2} \mathrm{O}_{2}$ production by canine neutrophils was measured (data not shown).

\section{Discussion}

PDBu induced NBT-reducing reaction of mature granulocytes even in the presence of kinase inhibitors, if an inhibitor of protein phosphatases was simultaneously present. The NBT-reducing reaction induced by tautomycin alone was inhibited by staurosporine. Tautomycin suppressed the inhibitory effect of structurally unrelated protein kinase inhibitors, such as H-7 and staurosporine. The suppression was also observed when tautomycin was added after the treatment of PDBu and staurosporine. However, tautomycin did not suppress the inhibitory effect of staurosporine in a cell-free system. Okadaic acid, the structure of which is different from tautomycin also suppressed the inhibitory effect of protein kinase 
inhibitors in vivo. Tautomycin did not suppress the inhibitory effect of staurosporine in a cell-free system. Furthermore, the recovery was also observed when tautomycin was added after the treatment of PDBu and staurosporine. These results suggest that direct competition of tautomycin and staurosporine or inhibition of uptake of staurosporine by tautomycin is unlikely. Thus, it is probable that PDBu induced NBT-reducing reaction in the presence of tautomycin or okadaic acid, even if the PKC activity is substantially suppressed by kinase inhibitors.

One could suggest that tautomycin diminishes the inhibitory effect of staurosporine since tautomycin increases protein phosphorylation by inhibition of protein phosphatases while staurosporine decreases it by inhibition of protein kinases. However, difference of $\mathrm{ID}_{50}$ of staurosporine in the presence and absence of tautomycin was more than 100 -fold that involved in respiratory burst. In addition, $\mathrm{H}_{2} \mathrm{O}_{2}$ was produced by a reaction with similar kinetics, in the presence or absence of tautomycin (Fig. 5). These results imply that respiratory burst was recovered not because tautomycin enhances the PKC-dependent phosphorylation which is suppressed by staurosporine, but because it by-passes respiratory burst by enhancing phosphorylation mediated by other kinase(s) distinct from PKC. Such kinase(s) should be staurosporine-resistant and constitutively active in the cells. This is largely in accord with the evidence. Most of the protein phosphorylations which were enhanced by tautomycin were resistant to staurosporine in vivo ${ }^{5}$.

In addition, it must be assumed that the $\mathrm{PKC}$-independent reaction induced by $\mathrm{PDBu}$ is also involved in respiratory burst because NBT-reducing reaction induced by tautomycin itself was sensitive to staurosporine. 4-p-BPB inhibited the NBT-reducing reaction, even in the presence of tautomycin. This result suggested that phorbol ester activates phospholipase $\mathrm{A}_{2}$ via activation of $\mathrm{PKC}^{14)}$. Thus, tautomycin may activate phospholipase $A_{2}$ through inhibition of dephosphorylation. Although further studies are necessary to elucidate the behavior of the kinases and phosphatases involved in the reaction, the present results suggest that phosphatases regulate respiratory burst of mature neutrophils in vivo.

\section{Acknowledgment}

We thank Dr. R. Gortsuka for the help in preparation of canine neutrophils. This work was partly supported by a Grant-in-Aid for Cancer Research from the Ministry of Education, Science and Culture, Japan, and a grant from New Energy and Industrial Technology Development Organization.

\section{References}

1) Cheng, X.-C.; T. Kihara, H. Kusakabe, J. Magae, Y. Kobayashi, R.-P. Fang, Z.-F. Ni, Y.-C. Shen, K. Ko, I. YAMAGUCHI \& K. Isono: A new antibiotic, tautomycin. J. Antibiotics 40: 907 909, 1987

2) Ubukata, M.; X.-C. Cheng \& K. Isono: The structure of tautomycin, a regulator of eukaryotic cell growth. J. Chem. Soc. Chem. Commun. 1990: 244 246, 1990

3) Cheng, X.-C.; M. Ubukata \& K. Isono: The structure of tautomycin, a dialkylmaleic anhydride antibiotic. J. Antibiotics 43: 809 819, 1990

4) Magae, J.; C. Watanabe, H. Osada, X.-C. Cheng \& K. Isono: Induction of morphological change of human myeloid leukemia and activation of protein kinase $\mathrm{C}$ by a novel antibiotic, tautomycin. J. Antibiotics 41 : 932 937, 1988

5) Magae, J.; H. Osada, H. Fujiki, T. C. Saldo, K. Suzuki, K. Nagai, M. Yamasaki \& K. Isono: Morphological changes of human myeloid leukemia K562 cells by a protein phosphatase inhibitor, tautomycin. Proc. Jpn. Acad. Ser. B 66: $209 \sim 212,1990$

6) MacKintosh, C. \& S. KlumpP: Tautomycin from the bacterium Streptomyces verticillatus. Another potent and specific inhibitor of protein phosphatases 1 and 2A. FEBS Lett. 227: $137 \sim 140,1990$

7) Hori, M.; J. Magae, Y.-G. Han, D. J. Hartshorne \& H. Karaki: A novel protein phosphatase inhibitor, tautomycin. Effect on smooth muscle. FEBS Lett. 285: 145 148, 1991

8) Ishihara, H.; B. L. Martin, D. L. Brautigan, H. Karaki, H. Ozaki, Y. Kato, N. Fusetani, S. Watabe, K. Hashimoto, D. Uemura \& D. J. Hartshorne: Calyculin A and okadaic acid: inhibitors of protein phosphatase activity. Biochem. Biophys. Res. Commun. 159: $871 \sim 877,1989$

9) Chartier, L.; L. L. Rankin, R. E. Allen, Y. Kato, N. Fusetani, H. Karaki, S. Watabe \& D. J. Hartshorne: Calyculin-A increases the level of protein phosphorylation and changes the shape of 3T3 fibroblasts. Cell Motil. Cytoskeleton 18: 41 54, 1991

10) MaGaE, J.; H. Osada, K. NaGai, M. Yamasaki \& K. Isono: Comparison of the effect of tautomycin and phorbol 
ester on protein kinase C in a cell-free system. J. Antibiotics 42: 1290 1293, 1989

1) CoHEN, M. S.; S. M. TAFFET \& D. O. AdAms: The relationship between competence for secretion of $\mathrm{H}_{2} \mathrm{O}_{2}$ and completion of tumor cytotoxicity by BCG-elicited murine macrophages. J. Immunol. 128: 1781 1785, 1982

12) Takai, A.; C. Blalojan, M. Troschka \& J. C. RuegG: Smooth muscle myosin phosphatase inhibition and force enhancement by black sponge toxin. FEBS Lett. 217: 81 84, 1987

13) Tachibana, K.; P. J. Scheuer, Y. Tsukitani, H. Kikuchi, D. V. Engen, J. Clardy, Y. Gopichand \& F. J. SCHMIT: Okadaic acid, a cytotoxic polyether from two marine sponges of the genus Halichondria. J. Am. Chem. Soc. 103: $2469 \sim 2471,1981$

14) Sakata, A.; E. IDA, M. Tominaga \& K. Onoue: Arachidonic acid as an intracellular activator of NADPH-oxidase in Fc receptor-mediated superoxide generation in macrophages. J. Immunol. 138: 4353 4359, 1987 